\title{
Phytoprotection
}

\section{Effects of nematicides on nematode population densities and crop yield in a turnip-corn-pea cropping system}

\author{
A.W. Johnson, C.C. Dowler, N. C. Glaze, D.R. Summer, R. B. Chalfant, A.M. \\ Golden et J.E. Epperson
}

Volume 71, numéro 2, 1990

URI : https://id.erudit.org/iderudit/705983ar

DOI : https://doi.org/10.7202/705983ar

\section{Aller au sommaire du numéro}

\section{Éditeur(s)}

Société de protection des plantes du Québec (SPPQ)l

ISSN

0031-9511 (imprimé)

1710-1603 (numérique)

Découvrir la revue

Citer cet article

Johnson, A., Dowler, C., Glaze, N., Summer, D., Chalfant, R., Golden, A. \& Epperson, J. (1990). Effects of nematicides on nematode population densities and crop yield in a turnip-corn-pea cropping system. Phytoprotection, 71(2), 55-63. https://doi.org/10.7202/705983ar

\section{Résumé de l'article}

Nous avons évalué quatre systèmes de conduite de cultures lors d'une étude de 6 ans afin de lutter contre les nematodes dans un système annuel de production de navet-maïs-pois sur des parcelles de sable loameux Tifton naturellement infestées par les Meloidogyne spp. (environ $90 \%$ de $M$. incognita et $10 \%$ de $M$. hapla), les Pratylenchus spp. (environ $65 \%$ de P. scribneri, $25 \%$ de $P$. brachyurus et $10 \%$ de P. zeae), ainsi que par les Paratrichodorus minor et Criconemella ornata. Le navet (Brassica campestris subsp. rapifera) a toléré de faibles quantités de tous les nematodes. Le maïs (Zea mays) 'Pioneer 3369A' a toléré de plus importantes quantités de tous les nematodes que le maïs 'Funks G-4507'. Les densités de population de juvéniles $\left(\mathrm{J}_{2}\right)$ de Meloidogyne spp. ont été abaissées en deçà de 80 par $150 \mathrm{~cm}^{3}$ de sol par un mélange composé de 98 $\%$ de bromure de méthyle et $2 \%$ de chloropicrine et par $20 \%$ de methyl isothiocyanate combiné à $80 \%$ d'hydrocarbones $\mathrm{C}_{3}$ chlorinés sur le navet et le maïs. Ces populations de nematodes ont augmente rapidement chez le pois (Vigna unguiculata) 'Pinkeye purplehull' mais ce ne fut pas le cas chez le cultivar Worthmore. Les densités de populations des autres nematodes n'ont pas été affectées par le cultivar de pois ou par le nématicide, en l'occurrence l'ethoprop. Le fenamiphos a été plus efficace que l'ethoprop en abaissant les densités de nematodes. Les augmentations de rendement du système intensif de conduite des cultures se sont échelonnées de $4 \%$ à $52 \%$ par rapport aux témoins non traités. 


\title{
Effects of nematicides on nematode population densities and crop yield in a turnip-corn-pea cropping system
}

\author{
A. W. Johnson, C. C. Dowler, and N. C. Glaze \\ USDA, ARS, Coastal Plain Station, Tifton, Georgia 31793, U.S.A.
}

D. R. Sumner

Department of Plant Pathology, University of Georgia, Coastal Plain Station, Tifton, Georgia 31793, U.S.A.

\section{R. B. Chalfant}

Department of Entomology, University of Georgia,

Coastal Plain Station, Tifton, Georgia 31793, U.S.A.

\author{
A. M. Golden \\ USDA, ARS, Beltsville, Maryland 20705, U.S.A.
}

\section{J. E. Epperson}

Department of Agricultural Economics, University of Georgia, Athens, Georgia 30602, U.S.A.

Four management systems were evaluated in a six-year study to control nematodes in a turnip-corn-pea annual cropping system on plots of Tifton loamy sand naturally infested with Meloidogyne spp. (about $90 \%$ M. incognita and $10 \% M$. hapla), Pratylenchus spp. (about $65 \%$ P. scribneri, $25 \%$ P. brachyurus, and $10 \%$ P. zeae), Paratrichodorus minor and Criconemella ornata. Turnip (Brassica campestris subsp. rapifera) supported low numbers of all nematodes. 'Pioneer 3369A' corn (Zea mays) supported greater numbers of all nematodes than 'Funks G-4507'. Population densities of Meloidogyne spp. juveniles $\left(\mathrm{J}_{2}\right)$ were suppressed below 80 per $150 \mathrm{~cm}^{3}$ of soil by $98 \%$ methyl bromide $+2 \%$ chloropicrin and $20 \%$ methyl isothiocyanate $+80 \%$ chlorinated $\mathrm{C}_{3}$ hydrocarbons on turnip and corn, and increased rapidly on 'Pinkeye purplehull', but not on a resistant cultivar, 'Worthmore' pea (Vigna unguiculata). Population densities of other nematodes were not affected by cultivar of pea or the nematicide, ethoprop. Fenamiphos was more effective than ethoprop in suppressing nematode population densities. Increases in crop yield in the intensive management system ranged from $4 \%$ to $52 \%$ over untreated controls.

Johnson, A. W., C. C. Dowler, N. C. Glaze, D. R. Sumner, R. B. Chalfant, A. M. Golden, and J. E. Epperson. 1990. Effects of nematicides on nematode population densities and crop yield in a turnip-corn-pea cropping system. PHYTOPROTECTION 71: 55-63.

Nous avons évalué quatre systèmes de conduite de cultures lors d'une étude de 6 ans afin de lutter contre les nématodes dans un système annuel de production de navet-maïs-pois sur des parcelles de sable loameux Tifton naturellement infestées par les Meloidogyne spp. (environ $90 \%$ de $M$. incognita et $10 \%$ de $M$. hapla), les Pratylenchus spp. (environ $65 \%$ de $P$. scribneri, $25 \%$ de $P$. brachyurus et $10 \%$ de $P$. zeae), ainsi que par les Paratrichodorus minor et Criconemella ornata. Le navet (Brassica campestris subsp. rapifera) a toléré de faibles quantités de tous les nématodes. Le maïs (Zea mays) 'Pioneer 3369A' a toléré de plus importantes quantités de tous les nématodes que le maïs 'Funks G-4507'. Les densités de populations de juvéniles $\left(\mathrm{J}_{2}\right)$ de Meloidogyne spp. ont été abaissées en-deçà de 80 par $150 \mathrm{~cm}^{3}$ de sol par un mélange composé de $98 \%$ de bromure de méthyle et $2 \%$ de chloropicrine et par $20 \%$ de méthyl isothiocyanate combiné à $80 \%$ d'hydrocarbones $\mathrm{C}_{3}$ chlorinés sur le navet et le maïs. Ces populations de nématodes ont augmenté rapidement chez le pois (Vigna unguiculata) 'Pinkeye purplehull' mais ce ne fut pas le cas chez le cultivar Worthmore. Les densités de populations des autres nématodes n'ont pas été affectées par le cultivar de pois ou par le nématicide, en l'occurence l'éthoprop. Le fenamiphos a été plus efficace que l'éthoprop en abaissant les densités de nématodes. Les augmentations de rendement du système intensif de conduite des cultures se sont échelonnées de $4 \%$ à $52 \%$ par rapport aux témoins non-traités. 


\section{Introduction}

In the southeastern United States, turnip (Brassica campestris subsp. rapifera [Metzg.] Sinsk.) may be planted in the spring or fall and grown from seed to maturity in about 60 days. The mature leaves may be picked by hand and sold on the fresh market. Much of the commercial production is harvested mechanically and processed as canned or frozen greens.

Corn (Zea mays L.) is grown in numerous crop rotations for grain or silage and with the long growing season it can be used in double or triple cropping with vegetables (Johnson et al. 1983).

Pea (Vigna unguiculata [L.] Walp.) is an important food crop from which a significant part of the world population obtains much of its dietary protein. Peas are grown commercially and in many home gardens in all except northern states of the United States, and are eaten as tender immature pods, green mature pods, mature green seeds, and dry seeds. Frequently, pea is grown in monocrop or double-crop systems in the spring or fall. Presently, all commercial production of pea in Georgia is under overhead sprinkler irrigation with a planned pest management program (Sumner et al. 1978).

Nematodes are important pests on corn and pea in monocrop and intensive cropping systems (Johnson and Fassuliotis 1984). Limited information is available on the effects of nematicides on nematode population densities and yield of turnip, corn, and pea in intensive cropping systems (Johnson et al. 1983). The objective of this study was to determine the effects of nematicides on nematode population densities and crop yield in a turnip-corn-pea cropping system.

\section{Material and methods}

Plots (three beds each $1.8 \mathrm{~m}$ wide and 7.7 $\mathrm{m}$ long) were established in September 1974 and maintained until December 1980 on Tifton loamy sand ( $85 \%$ sand, $10 \%$ silt, $5 \%$ clay, $0.5 \%$ organic matter and $\mathrm{pH}$ 6.0-6.7) naturally infested initially with Meloidogyne spp. (about 90\% Meloidogyne incognita [Kofoid \& White] Chitwood, race 1, and $10 \%$ Meloidogyne hapla Chitwood), Pratylenchus spp. (about $65 \%$ Pratylenchus scribneri Steiner, $25 \%$ Pratylenchus brachyurus [Godfrey] Filip. \& Sch.-Stek., and $10 \%$ Pratylenchus zeae Graham), Paratrichodorus minor (Colbran) Siddiqi, and Crinconemella ornata (Raski) Luc and Raski.

Nematicide treatments. The four treatments were replicated six times in a randomized complete block design. For the first treatment (MBR-CP), the soil was treated between 14 November and 8 February each year with $358.7 \mathrm{~kg} /$ ha MBR-CP (98\% methyl bromide $+2 \%$ chloropicrin, DOWFUME MC-2) injected throughout a $25-\mathrm{cm}$ layer with chisels $20 \mathrm{~cm}$ apart. The soil surface was shaped and sealed with a bed-shaper, and plots were covered with black polyethylene $(152 \mu \mathrm{m}$ thick). The polyethylene was removed from the plots $48 \mathrm{~h}$ after soil treatment. For the second treatment (DD-MENCS), the soil was treated between 14 November and 17 December each year with $376.6 \mathrm{~kg} / \mathrm{ha}$ DD-MENCS $(20 \%$ methyl isothiocyanate $+80 \%$ chlorinated $\mathrm{C}_{3}$ hydrocarbons, VORLEX) as described for MBR-CP, except the plots were not covered with polyethylene. In the third treatment (E-F), ethoprop ( $O$-ethyl $S, S$-dipropyl phosphorodithioate, MOCAP 10G) was applied at $8.96 \mathrm{~kg}$ a.i. / ha overall to the soil surface and incorporated into the top $15 \mathrm{~cm}$ with a tractor-driven rototiller before planting each crop from 1975 to 1978 . However, poor nematode control was obtained. Therefore, fenamiphos (Ethyl 3-methyl-4-(methylthio) phenyl(1-methylethyl) phosphoramidateNEMACUR 15G) was applied at $8.96 \mathrm{~kg}$ a.i./ha in 1979 and 1980 as described for ethoprop. No nematicides were used in the untreated plots. Additional pesticides to control other pests were applied to crops grown under the four nematicide treatments and are listed in Table 1.

Plot establishment. The soil was discharrowed, plowed $15-20 \mathrm{~cm}$ deep, and shaped into beds $1.8 \mathrm{~m}$ wide and 10 to $15 \mathrm{~cm}$ high with a rototiller before planting each crop. The annual cropping sequence was turnip, corn, and pea. Turnip cv. Shogoin was planted in February and harvested in March or April. Immediately after turnip was harvested, plots were subsoiled 45 to $60 \mathrm{~cm}$ deep with chisels $91 \mathrm{~cm}$ apart, 
and a nonvolatile nematicide and other pesticides were applied (Table 1). Corn cv. Pioneer 3369A (1975-1978) or Funks G-4507 (1979-1980) was planted 1 to 8 days later and harvested in August. Pea was planted 2 to 7 days after corn harvest and was harvested in October. Cultivar Pinkeye purplehull used between 1975 and 1978 was susceptible to $M$. incognita and $M$. arenaria Chitwood, but resistant to $M$. hapla and $\mathrm{cv}$. Worthmore used in 1979 and 1980 was susceptible to $M$. arenaria, but resistant to $M$. incognita and $M$. hapla (J. D. Gay and R. E. Motsinger, personal communication). Plots were disc-harrowed after pea harvest and clean-fallowed until turnip was planted.

The nematicide treatments were maintained on the same land unit for the duration of the experiment. Supplemental irrigation was supplied as needed to enhance seedling emergence and plant growth when natural rainfall was insufficient. Liquid formulations of nitrogen $(\mathrm{N})$, phosphorus $(\mathrm{P})$, and potassium $(\mathrm{K})(10-34-0$, a $32 \%$ solution of $\mathrm{NH}_{4} \mathrm{NO}_{3}$-urea, and 0-0-60 KCl) were applied broadcast via irrigation system in multiple applications after planting each crop. The total $\mathrm{kg}$ per ha N-P-K applied to each crop each year was $123,45,90$ for turnip; 308, 39, 100 for corn; and 22, 22, 84 for pea. Yield was taken on $7.7 \mathrm{~m}$ of the center bed.

Twenty soil samples $(2.5 \mathrm{~cm}$ in diameter and $15 \mathrm{~cm}$ deep) were collected monthly from 1975 to 1980 from within the rows adjacent to the center bed, composited, and thoroughly mixed. A $150-\mathrm{cm}^{3}$ subsample was assayed for plant-parasitic nematodes by the centrifugal flotation method (Jenkins 1964).

Table 1. Pesticides applied to crops grown under four nematicide treatments in a turnip-corn-pea intensive cropping system (1975-1980)

\begin{tabular}{|c|c|c|c|}
\hline Nematicide treatment & Pesticide applied (year) & $\begin{array}{c}\text { Rate } \\
\text { (kg a.i./ha) }\end{array}$ & Crop \\
\hline$\overline{\mathrm{MBR}-\mathrm{CP}^{\S}}$ & $\begin{array}{l}\text { Carbofuran (1978-1980) } \\
\text { Methomyl (1976) }\end{array}$ & $\begin{array}{l}2.24 \\
0.50\end{array}$ & $\begin{array}{l}\text { Corn } \\
\text { Corn }\end{array}$ \\
\hline DD-MENCS ${ }^{\dagger}$ & $\begin{array}{l}\text { DCPA }(1975-1980) \\
\text { Butylate }(1975-1977) \\
\text { Cyanazine }(1977-1980) \\
\text { 2,4-D (1976-1980) } \\
\text { Paraquat }(1977) \\
\text { Pendimethalin }(1978-1980) \\
\text { Methomyl (1976) } \\
\text { Carbofuran }(1977-1980) \\
\text { Trifluralin }(1977-1980) \\
\text { Dinoseb (1975-1980) }\end{array}$ & $\begin{array}{l}4.48 \\
4.48 \\
1.40 \\
0.28 \\
0.28 \\
0.84 \\
0.50 \\
2.24 \\
0.56 \\
1.68\end{array}$ & $\begin{array}{l}\text { Turnip } \\
\text { Corn } \\
\text { Corn } \\
\text { Corn } \\
\text { Corn } \\
\text { Corn } \\
\text { Corn } \\
\text { Corn } \\
\text { Pea } \\
\text { Pea }\end{array}$ \\
\hline E-F $F^{\ddagger}$ & $\begin{array}{l}\text { DCPA (1975-1980) } \\
\text { Butylate }(1975-1977) \\
\text { Cyanazine (1977-1980) } \\
\text { Paraquat (1977) } \\
\text { Pendimethalin (1978-1980) } \\
\text { Methomyl (1976) } \\
\text { Carbofuran (1978-1980) } \\
\text { Trifluralin (1975-1980) } \\
\text { Dinoseb (1975-1980) }\end{array}$ & $\begin{array}{l}4.48 \\
8.96 \\
1.34 \\
0.28 \\
0.84 \\
0.50 \\
2.24 \\
0.56 \\
1.68\end{array}$ & $\begin{array}{l}\text { Turnip } \\
\text { Corn } \\
\text { Corn } \\
\text { Corn } \\
\text { Corn } \\
\text { Corn } \\
\text { Corn } \\
\text { Pea } \\
\text { Pea }\end{array}$ \\
\hline Untreated & $\begin{array}{l}\text { DCPA }(1975-1980) \\
\text { Butylate }(1975-1977) \\
2,4-D(1976-1978) \\
\text { Pendimethalin }(1978-1980) \\
\text { Trifluralin }(1975-1980)\end{array}$ & $\begin{array}{l}4.48 \\
8.96 \\
0.28 \\
0.84 \\
0.56\end{array}$ & $\begin{array}{l}\text { Turnip } \\
\text { Corn } \\
\text { Corn } \\
\text { Corn } \\
\text { Pea }\end{array}$ \\
\hline
\end{tabular}

$\S$ Plots maintained weedfree by handweeding.

$\dagger$ Plots maintained weedfree by additional handweeding and cultivation.

$\ddagger$ E-F: Ethoprop (1975-1978) and fenamiphos (1979-1980) used on each crop. Herbicides, cultivation, and insecticides used only as needed to control weeds and insects.

I No nematicide; one herbicide and cultivation were used to control weeds. 
Statistical analyses. The data for the nematode populations presented in the tables were obtained from the treatment means for each month in 1975-1978 for turnip, 'Pioneer 3369A' corn and 'Pinkeye purplehull' pea and in 1979-1980 for turnip, 'Funks G-4507' corn and 'Worthmore' pea. Data were analyzed as a randomized complete block design with least-squares analysis of variance (Steel and Torrie 1960) and Waller-Duncan K-ratio $t$-test (Waller and Duncan 1969). Correlation coefficients $(r)$ were determined for yield of crops and nematode population densities in the soil each month during 1975-1980.

\section{Results}

Meloidogyne incognita was the most prevalent plant-parasitic nematode in the soil. The mean number of $M$. incognita juveniles $\left(\mathrm{J}_{2}\right)$ in untreated plots decreased to 22 per $150 \mathrm{~cm}^{3}$ of soil on turnip and increased to 878 and 1103 per $150 \mathrm{~cm}^{3}$ of soil in 'Pioneer 3369A' corn and 'Pinkeye purplehull' pea, respectively, in 1975-1978 (Table 2). MBR-CP and DD-MENCS prevented rapid increase of $M$. incognita in corn, but not in 'Pinkeye purplehull' pea. The mean number of $\mathrm{J}_{2}$ in plots of corn and 'Pinkeye purplehull' pea treated with ethoprop (1975-1978) did not differ from those in untreated plots. However, in 1979-1980 the density of $J_{2}$ was reduced in 'Funks G-4507' corn treated with fenamiphos and in 'Worthmore' pea (Table 2). The root-knot nematode species identified from roots of 'Pinkeye purplehull' pea in 1977 was $M$. incognita.

Table 2. Effect of nematicide treatments on population densities of Meloidogyne incognita juveniles in a turnipcorn-pea fallow cropping system

\begin{tabular}{|c|c|c|c|c|c|c|c|}
\hline \multirow[b]{2}{*}{ Year } & \multirow{2}{*}{$\begin{array}{l}\text { Month of } \\
\text { sampling }\end{array}$} & \multirow{2}{*}{$\begin{array}{l}\text { Cropping } \\
\text { sequence }\end{array}$} & \multicolumn{4}{|c|}{$\begin{array}{c}\text { Density } \\
\text { (number per } 150 \mathrm{~cm}^{3} \text { ) }\end{array}$} & \multirow{2}{*}{$\begin{array}{l}\text { LSD } \\
(0.05)\end{array}$} \\
\hline & & & MBR-CP & DD-MENCS & Ethoprop & Untreated & \\
\hline $1975-1978$ & $\begin{array}{l}\text { January } \\
\text { February } \\
\text { March } \\
\text { April } \\
\text { May } \\
\text { June } \\
\text { July } \\
\text { August } \\
\text { September } \\
\text { October } \\
\text { November } \\
\text { December }\end{array}$ & $\begin{array}{l}\text { Fallow } \\
\text { Fallow } \\
\text { Turnip } \\
\text { Turnip } \\
\text { Corn } \\
\text { Corn } \\
\text { Corn } \\
\text { Corn } \\
\text { Pea }^{\ddagger} \\
\text { Pea } \\
\text { Fallow } \\
\text { Fallow }\end{array}$ & $\begin{array}{r}36 \\
9 \\
41 \\
0 \\
0 \\
0 \\
1 \\
32 \\
4 \\
610 \\
942 \\
249\end{array}$ & $\begin{array}{r}77 \\
4 \\
4 \\
0 \\
0 \\
0 \\
0 \\
6 \\
6 \\
416 \\
812 \\
264\end{array}$ & $\begin{array}{r}248 \\
134 \\
42 \\
9 \\
9 \\
13 \\
342 \\
871 \\
151 \\
931 \\
1001 \\
535\end{array}$ & $\begin{array}{r}192 \\
85 \\
49 \\
22 \\
10 \\
23 \\
389 \\
878 \\
187 \\
1103 \\
859 \\
545\end{array}$ & 565 \\
\hline Year & $\begin{array}{l}\text { Month of } \\
\text { sampling }\end{array}$ & $\begin{array}{l}\text { Cropping } \\
\text { sequence }\end{array}$ & MBR-CP & DD-MENCS & Fenamiphos & Untreated & $\begin{array}{l}\text { LSD } \\
(0.05)\end{array}$ \\
\hline 1979-1980 & $\begin{array}{l}\text { January } \\
\text { February } \\
\text { March } \\
\text { April } \\
\text { May } \\
\text { June } \\
\text { July } \\
\text { August } \\
\text { September } \\
\text { October } \\
\text { November } \\
\text { December }\end{array}$ & $\begin{array}{l}\text { Fallow } \\
\text { Fallow } \\
\text { Turnip } \\
\text { Turnip } \\
\text { Corn } \\
\text { Corn } \\
\text { Corn } \\
\text { Corn } \\
\text { Pea } \\
\text { Pea } \\
\text { Fallow } \\
\text { Fallow } \\
\end{array}$ & $\begin{array}{r}30 \\
7 \\
0 \\
1 \\
1 \\
0 \\
1 \\
42 \\
4 \\
17 \\
3 \\
5 \\
\end{array}$ & $\begin{array}{r}8 \\
0 \\
1 \\
0 \\
0 \\
0 \\
0 \\
56 \\
4 \\
2 \\
2 \\
6 \\
\end{array}$ & $\begin{array}{r}58 \\
71 \\
13 \\
17 \\
17 \\
0 \\
1 \\
1 \\
1 \\
0 \\
0 \\
1 \\
\end{array}$ & $\begin{array}{r}85 \\
85 \\
31 \\
10 \\
4 \\
18 \\
151 \\
1746 \\
222 \\
71 \\
79 \\
28 \\
\end{array}$ & 752 \\
\hline $\begin{array}{ll}\S & \text { Means } ~ \\
\dagger & \text { Cultivar } \\
\ddagger & \text { Cultivar } \\
\uparrow & \text { LSD for }\end{array}$ & $\begin{array}{l}\text { eplicates. } \\
\text { er 3369A in } \\
\text { ent purplehu } \\
\text { enteatmer }\end{array}$ & $\begin{array}{l}1975-1978, \\
\text { in } 1975-19 \\
\text { in the sam }\end{array}$ & $\begin{array}{l}\text { inks G-4507 } \\
\text { Worthmor } \\
\text { month. }\end{array}$ & $\begin{array}{l}\text { in } 1979-1980 \\
\text { e in } 1979-1980\end{array}$ & & & \\
\hline
\end{tabular}


The mean number of Paratrichodorus minor did not increase above 21 per $150 \mathrm{~cm}^{3}$ of soil in turnip or pea, but increased rapidly in corn following treatment with MBR-CP and DD-MENCS (Table 3). The numbers of $P$. minor were greater in corn in July than at any other sampling date during each year. Paratrichodorus minor densities in plots of 'Pioneer 3369A' treated with ethoprop (1975-1978) were not different from those in untreated plots, but the density was lower in plots of 'Funks G-4507' treated with fenamiphos (1979-1980) than in untreated plots in June (Table 3).

The mean number of Criconemella ornata was greater in 'Pioneer 3369A' corn in August than in other crops and was not affected by ethoprop (1975-1978) (Table 4).
Population densities of $C$. ornata in all crops were less than 16 per $150 \mathrm{~cm}^{3}$ of soil in plots treated with MBR-CP, DD-MENCS and fenamiphos (1979-1980) on all sampling dates.

The mean number of Pratylenchus spp. in untreated plots was greatest in 'Pioneer 3369A' corn in August (1975-1978) (Table 5). Ethoprop suppressed population densities of Pratylenchus spp. on 'Pioneer 3369A' corn in August 1975-1978 compared with untreated control. Population densities of Pratylenchus spp. were less than 8 per $150 \mathrm{~cm}^{3}$ of soil in all crops for plots treated with MBR-CP, DD-MENCS and fenamiphos on all sampling dates (Table 5). Pratylenchus species identified from roots of corn were as follows: 1975 P. brachyurus (92\%), P. scribneri (5\%),

Table 3. Effect of nematicide treatments on population densities of Paratrichodorus minor in a turnip-corn-pea fallow cropping system

\begin{tabular}{|c|c|c|c|c|c|c|c|}
\hline \multirow[b]{2}{*}{ Year } & \multirow{2}{*}{$\begin{array}{l}\text { Month of } \\
\text { sampling }\end{array}$} & \multirow{2}{*}{$\begin{array}{l}\text { Cropping } \\
\text { sequence }\end{array}$} & \multicolumn{4}{|c|}{$\begin{array}{c}\text { Density } \\
\text { (number per } 150 \mathrm{~cm}^{3} \text { ) }\end{array}$} & \multirow{2}{*}{$\begin{array}{l}\mathrm{LSD} \\
(0.05)\end{array}$} \\
\hline & & & MBR-CP & DD-MENCS & Ethoprop & Untreated & \\
\hline \multirow[t]{12}{*}{$1975-1978$} & January & Fallow & 1 & 3 & 5 & 2 & 32 \\
\hline & February & Fallow & 1 & 1 & 3 & 3 & \\
\hline & March & Turnip & 0 & 0 & 2 & 3 & \\
\hline & April & Turnip & 0 & 0 & 3 & 7 & \\
\hline & May & $\operatorname{Corn}^{\dagger}$ & 0 & 1 & 8 & 15 & \\
\hline & June & Corn & 17 & 32 & 17 & 44 & \\
\hline & July & Corn & 72 & 45 & 24 & 27 & \\
\hline & August & Corn & 26 & 22 & 10 & 4 & \\
\hline & September & $\mathrm{Pea}^{\ddagger}$ & 14 & 9 & 6 & 6 & \\
\hline & October & Pea & 4 & 5 & 1 & 3 & \\
\hline & November & Fallow & 5 & 3 & 1 & 6 & \\
\hline & December & Fallow & 8 & 2 & 4 & 4 & \\
\hline Year & $\begin{array}{l}\text { Month of } \\
\text { sampling }\end{array}$ & $\begin{array}{l}\text { Cropping } \\
\text { sequence }\end{array}$ & MBR-CP & DD-MENCS & Fenamiphos & Untreated & $\begin{array}{l}\text { LSD ब } \\
(0.05) \\
\end{array}$ \\
\hline \multirow[t]{12}{*}{$1979-1980$} & January & Fallow & 0 & 0 & 1 & 1 & 50 \\
\hline & February & Fallow & 0 & 0 & 4 & 1 & \\
\hline & March & Turnip & 1 & 0 & 3 & 7 & \\
\hline & April & Turnip & 1 & 1 & 3 & 6 & \\
\hline & May & Corn $^{\dagger}$ & 6 & 5 & 2 & 7 & \\
\hline & June & Corn & 74 & 102 & 1 & 91 & \\
\hline & July & Corn & 179 & 182 & 26 & 55 & \\
\hline & August & Corn & 15 & 11 & 3 & 8 & \\
\hline & September & $\mathrm{Pea}^{\ddagger}$ & 3 & 5 & 0 & 3 & \\
\hline & October & Pea & 21 & 16 & 1 & 1 & \\
\hline & November & Fallow & 5 & 3 & 0 & 3 & \\
\hline & December & Fallow & 4 & 1 & 1 & 2 & \\
\hline
\end{tabular}

$\S$ Means of six replicates.

$\dagger$ Cultivar Pioneer 3369A in 1975-1978, Funks G-4507 in 1979-1980.

$\ddagger$ Cultivar Pinkeye purplehull in 1975-1978, Worthmore in 1979-1980.

I LSD for different treatments in the same month. 
Table 4. Effect of nematicide treatments on population densities of Criconemella ornata in a turnip-corn-pea fallow cropping system

\begin{tabular}{|c|c|c|c|c|c|c|c|}
\hline \multirow[b]{2}{*}{ Year } & \multirow[b]{2}{*}{$\begin{array}{l}\text { Month of } \\
\text { sampling }\end{array}$} & \multirow[b]{2}{*}{$\begin{array}{l}\text { Cropping } \\
\text { sequence }\end{array}$} & \multicolumn{4}{|c|}{$\begin{array}{c}\text { Density } \\
\text { (number per } 150 \mathrm{~cm}^{3} \text { ) }\end{array}$} & \multirow[b]{2}{*}{$\begin{array}{l}\mathrm{LSD}^{\top} \\
(0.05)\end{array}$} \\
\hline & & & MBR-CP & DD-MENCS & Ethoprop & Untreated & \\
\hline \multirow{12}{*}{$1975-1978$} & January & Fallow & 60 & 31 & 38 & 30 & 75 \\
\hline & February & Fallow & 2 & 1 & 49 & 27 & \\
\hline & March & Turnip & 1 & 2 & 28 & 23 & \\
\hline & April & Turnip & 0 & 1 & 43 & 27 & \\
\hline & May & Corn $^{\dagger}$ & 1 & 2 & 52 & 31 & \\
\hline & June & Corn & 1 & 3 & 53 & 48 & \\
\hline & July & Corn & 1 & 8 & 131 & 111 & \\
\hline & August & Corn & 6 & 7 & 175 & 227 & \\
\hline & September & $\mathrm{Pea}^{\ddagger}$ & 6 & 4 & 80 & 59 & \\
\hline & October & Pea & 7 & 8 & 27 & 36 & \\
\hline & November & Fallow & 2 & 4 & 34 & 18 & \\
\hline & December & Fallow & 5 & 1 & 22 & 16 & \\
\hline Year & $\begin{array}{l}\text { Month of } \\
\text { sampling }\end{array}$ & $\begin{array}{l}\text { Cropping } \\
\text { sequence }\end{array}$ & MBR-CP & DD-MENCS & Fenamiphos & Untreated & $\begin{array}{l}\mathrm{LSD}^{\top} \\
(0.05)\end{array}$ \\
\hline \multirow[t]{12}{*}{$1979-1980$} & January & Fallow & 1 & 0 & 10 & 7 & 19 \\
\hline & February & Fallow & 0 & 0 & 5 & 4 & \\
\hline & March & Turnip & 0 & 0 & 1 & 5 & \\
\hline & April & Turnip & 0 & 0 & 5 & 8 & \\
\hline & May & $\operatorname{Corn}^{\dagger}$ & 0 & 0 & 15 & 13 & \\
\hline & June & Corn & 0 & 0 & 6 & 19 & \\
\hline & July & Corn & 1 & 1 & 3 & 35 & \\
\hline & August & Corn & 0 & 0 & 1 & 128 & \\
\hline & September & $\mathrm{Pea}^{\ddagger}$ & 0 & 1 & 0 & 49 & \\
\hline & October & Pea & 0 & 1 & 1 & 19 & \\
\hline & November & Fallow & 1 & 0 & 0 & 20 & \\
\hline & December & Fallow & 0 & 1 & 1 & 18 & \\
\hline
\end{tabular}

$\S$ Means of six replicates.

$\dagger$ Cultivar Pioneer 3369A in 1975-1978, Funks G-4507 in 1979-1980.

\$ Cultivar Pinkeye purplehull in 1975-1978, Worthmore in 1979-1980.

I LSD for different treatments in the same month.

P. zeae $(3 \%) ; 1977$ - P. scribneri $(32 \%)$, $P$. zeae $(68 \%)$; and 1979 - P. brachyurus (7\%), P. scribneri (69\%), and P. zeae $(24 \%)$. Those identified from roots of 'Pinkeye purplehull' pea in 1977 were $P$. brachyurus in four blocks and $P$. scribneri in two blocks.

Generally the yield of turnip was greater from MBR-CP than other treatments (Table 6). Yield was greater from plots treated with DD-MENCS compared with untreated plots in 1977 and 1979. The mean yield data across all years indicate a $41 \%$ increase from MBR-CP treatment and a $4 \%$ and $15 \%$ decrease from DD-MENCS and E-F treatments, respectively, as compared to yields from untreated plots.

Yield of 'Pioneer 3369A' corn was consistently greater from plots treated with
MBR-CP, except in 1975, and from DDMENCS than from untreated plots (Table 6). The application of ethoprop prior to planting 'Pioneer 3369A' corn did not result in yield increase. Yield of 'Funks G-4507' was not affected by the treatments. The mean yield of 'Pioneer 3369A' across years and treatments was $8 \%$ greater than yield of 'Funks G-4507'.

Yield from 'Pinkeye purplehull' pea was consistently greater from plots treated with MBR-CP and DD-MENCS than from untreated plots (Table 6). The application of ethoprop prior to planting 'Pinkeye purplehull' did not increase yields $(P \leq 0.05)$ over untreated plots. The mean yield data across years indicate a $52 \%, 51 \%$ and $9 \%$ increase, respectively, from MBR-CP, DDMENCS and ethoprop treatments over 
Table 5. Effect of nematicide treatments on population densities of Pratylenchus spp. in a turnip-corn-pea fallow cropping system

\begin{tabular}{|c|c|c|c|c|c|c|c|}
\hline \multirow[b]{2}{*}{ Year } & \multirow[b]{2}{*}{$\begin{array}{l}\text { Month of } \\
\text { sampling }\end{array}$} & \multirow[b]{2}{*}{$\begin{array}{l}\text { Cropping } \\
\text { sequence }\end{array}$} & \multicolumn{4}{|c|}{$\begin{array}{c}\text { Density } \\
\text { (number per } 150 \mathrm{~cm}^{3} \text { ) }\end{array}$} & \multirow[b]{2}{*}{$\begin{array}{l}\text { LSD } \\
(0.05)\end{array}$} \\
\hline & & & MBR-CP & DD-MENCS & Ethoprop & Untreated & \\
\hline \multirow[t]{12}{*}{$1975-1978$} & January & Fallow & 10 & 9 & 17 & 18 & 23 \\
\hline & February & Fallow & 1 & 1 & 12 & 17 & \\
\hline & March & Turnip & 0 & 0 & 12 & 13 & \\
\hline & April & Turnip & 0 & 0 & 5 & 11 & \\
\hline & May & $\operatorname{Corn}^{+}$ & 1 & 1 & 3 & 5 & \\
\hline & June & Corn & 0 & 0 & 1 & 3 & \\
\hline & July & Corn & 0 & 0 & 4 & 10 & \\
\hline & August & Corn & 1 & 0 & 22 & 47 & \\
\hline & September & $\mathrm{Pea}^{\ddagger}$ & 1 & 1 & 14 & 51 & \\
\hline & October & Pea & 1 & 0 & 5 & 7 & \\
\hline & November & Fallow & 0 & 0 & 6 & 20 & \\
\hline & December & Fallow & 1 & 1 & 6 & 8 & \\
\hline Year & $\begin{array}{l}\text { Month of } \\
\text { sampling }\end{array}$ & $\begin{array}{l}\text { Cropping } \\
\text { sequence }\end{array}$ & MBR-CP & DD-MENCS & Fenamiphos & Untreated & $\begin{array}{l}\text { LSD } \\
(0.05) \\
\end{array}$ \\
\hline \multirow[t]{12}{*}{$1979-1980$} & January & Fallow & 1 & 0 & 0 & 3 & 11 \\
\hline & February & Fallow & 0 & 0 & 1 & 5 & \\
\hline & March & Turnip & 0 & 0 & 1 & 2 & \\
\hline & April & Turnip & 1 & 0 & 1 & 3 & \\
\hline & May & $\operatorname{Corn}^{\dagger}$ & 0 & 0 & 0 & 2 & \\
\hline & June & Corn & 0 & 0 & 0 & 0 & \\
\hline & July & Corn & 1 & 0 & 0 & 2 & \\
\hline & August & Corn & 1 & 0 & 0 & 12 & \\
\hline & September & $\mathrm{Pea}^{\ddagger}$ & 7 & 0 & 0 & 27 & \\
\hline & October & Pea & 3 & 2 & 0 & 6 & \\
\hline & November & Fallow & 0 & 0 & 0 & 12 & \\
\hline & December & Fallow & 2 & 2 & 0 & 14 & \\
\hline
\end{tabular}

$\S$ Means of six replicates.

$\dagger$ Cultivar Pioneer 3369A in 1975-1978, Funks G-4507 in 1979-1980.

$\ddagger$ Cultivar Pinkeye purplehull in 1975-1978, Worthmore in 1979-1980.

I LSD for different treatments in the same month.

untreated plots. Yield of 'Worthmore' pea was greater from plots treated with MBR$\mathrm{CP}$ and fenamiphos in 1979 and DDMENCS in 1980 than yields from untreated plots. The mean yield data across years for 'Worthmore' pea showed a $13 \%, 9 \%$ and $9 \%$ increase, respectively, from MBR-CP, DD-MENCS and fenamiphos treatments over untreated plots. Mean data across treatments and years indicate that yields of 'Worthmore' were $85 \%$ greater than 'Pinkeye purplehull' pea.

All correlation coefficients presented were significant $(P \leq 0.05)$ unless stated otherwise. There were no relationships $(P \leq 0.05)$ between yield of turnip and total numbers of nematodes ( $r=-0.05$ to 0.15 ) in the soil from time of planting the crop until harvest. However, there were inverse relationships between yield of turnip and numbers of Meloidogyne incognita $\mathrm{J}_{2}(r=$ -0.18 to -0.28 ) in the soil during clean fallow in November, December, and January before seeding turnip.

Inverse relationships between numbers of nematodes in the soil at or near planting in April and May and yield of 'Pioneer 3369A' corn ranged from $r=-0.22$ to -0.35 , but the inverse relationships decreased with time until harvest. Negative correlations were determined between numbers of Meloidogyne incognita $\mathrm{J}_{2}(r=-0.46)$ in the soil in May and yield of 'Funks G-4507' corn. Correlation coefficients indicated a negative relationship between all nematodes $(r=-0.20$ to -0.25$)$ except $C$. ornata, and $P$. minor, in the soil in September and October and yield of 'Pinkeye purplehull' pea. There were negative correlations among numbers of $C$. ornata, $(r=-0.30)$ 
Table 6. Yield (t/ha) of turnip, corn, and pea as affected by the nematicide treatments in an intensive cropping system

\begin{tabular}{lcrrrrr}
\hline & \multicolumn{7}{c}{ Turnip } \\
\cline { 2 - 7 } Treatment $^{\S}$ & 1975 & 1976 & 1977 & 1978 & 1979 & 1980 \\
\hline MBR-CP & $20.19 \mathrm{a}^{\dagger}$ & $23.10 \mathrm{a}$ & $18.24 \mathrm{a}$ & $24.81 \mathrm{a}$ & $25.05 \mathrm{a}$ & $9.00 \mathrm{a}$ \\
DD-MENCS & $10.45 \mathrm{~b}$ & $4.13 \mathrm{c}$ & $10.94 \mathrm{~b}$ & $20.92 \mathrm{ab}$ & $25.78 \mathrm{a}$ & $9.97 \mathrm{a}$ \\
E-F & $12.40 \mathrm{~b}$ & $11.19 \mathrm{~b}$ & $5.11 \mathrm{c}$ & $13.13 \mathrm{c}$ & $21.89 \mathrm{~b}$ & $9.48 \mathrm{a}$ \\
Untreated & $12.40 \mathrm{~b}$ & $21.64 \mathrm{a}$ & $4.86 \mathrm{c}$ & $15.81 \mathrm{bc}$ & $21.89 \mathrm{~b}$ & $9.00 \mathrm{a}$
\end{tabular}

\begin{tabular}{|c|c|c|c|c|c|c|}
\hline & \multicolumn{6}{|c|}{ Corn } \\
\hline & \multicolumn{4}{|c|}{ cv. Pioneer 3369A } & \multicolumn{2}{|c|}{ cv. Funks Gi-4507 } \\
\hline & 1975 & 1976 & 1977 & 1978 & 1979 & 1980 \\
\hline MBR-CP & $12.12 \mathrm{~b}$ & $16.00 \mathrm{a}$ & $13.62 \mathrm{a}$ & $14.71 \mathrm{a}$ & $12.67 \mathrm{a}$ & $12.67 \mathrm{a}$ \\
\hline DD-MENCS & $13.96 \mathrm{a}$ & $15.73 \mathrm{a}$ & $13.62 \mathrm{a}$ & $13.48 \mathrm{~b}$ & $12.53 \mathrm{a}$ & $12.60 \mathrm{a}$ \\
\hline E-F & $12.87 \mathrm{~b}$ & $12.87 \mathrm{c}$ & $12.73 \mathrm{ab}$ & $13.21 \mathrm{bc}$ & $11.30 \mathrm{a}$ & $13.21 \mathrm{a}$ \\
\hline \multirow[t]{4}{*}{ Untreated } & $11.98 \mathrm{~b}$ & $14.14 \mathrm{~b}$ & $11.85 \mathrm{~b}$ & $12.46 \mathrm{c}$ & $11.64 \mathrm{a}$ & $12.39 \mathrm{a}$ \\
\hline & \multicolumn{6}{|c|}{ Pea } \\
\hline & \multicolumn{4}{|c|}{ cv. Pinkeye purplehull } & \multicolumn{2}{|c|}{ cv. Worthmore } \\
\hline & 1975 & 1976 & 1977 & 1978 & 1979 & 1980 \\
\hline MBR-CP & $1.79 \mathrm{a}$ & $0.89 \mathrm{a}$ & $1.79 \mathrm{a}$ & $2.06 \mathrm{a}$ & $2.47 \mathrm{ab}$ & $2.85 \mathrm{ab}$ \\
\hline DD-MENCS & $1.50 \mathrm{ab}$ & $0.85 \mathrm{a}$ & $1.86 \mathrm{a}$ & $2.28 \mathrm{a}$ & $2.21 \mathrm{bc}$ & $2.93 \mathrm{a}$ \\
\hline $\mathrm{E}-\mathrm{F}$ & $1.47 \mathrm{ab}$ & $0.59 \mathrm{ab}$ & $1.29 \mathrm{~b}$ & $1.32 \mathrm{~b}$ & $2.58 \mathrm{a}$ & $2.51 \mathrm{~b}$ \\
\hline Untreated & $1.22 \mathrm{~b}$ & $0.42 \mathrm{~b}$ & $1.11 \mathrm{~b}$ & $1.54 \mathrm{~b}$ & $2.08 \mathrm{c}$ & $2.63 \mathrm{~b}$ \\
\hline
\end{tabular}

$\S$ MBR-CP $=98 \%$ methyl bromide $+2 \%$ chloropicrin; DD-MENCS $=20 \%$ methyl isothiocyanate $+80 \%$ chlorinated $\mathrm{C}_{3}$ hydrocarbons; $\mathrm{E}-\mathrm{F}=$ ethoprop (1975-1978) and fenamiphos (1979-1980); and untreated = no nematicide.

$\dagger$ Means followed by different letters in columns are significantly $(P \leq 0.05)$ different according to WallerDuncan K-ratio $t$-test.

and Meloidogyne incognita $\mathrm{J}_{2}(r=-0.35)$ in the soil in September and October respectively, and yield of 'Worthmore' pea.

\section{Discussion}

Soil fumigation with MBR-CP and DDMENCS reduced densities of nematodes and increased yields of crops, but treatments were not economically feasible (Epperson $e t$ al. 1982). The rapid increase in numbers of $M$. incognita $\mathrm{J}_{2}$ in 'Pinkeye purplehull' pea in fumigated soil following corn supports results reported for intensive cropping systems under film mulch and trickle irrigation (Johnson et al. 1979). Also, the increase in numbers of $P$. minor following soil fumigation supports other results (Perry 1953).

Fenamiphos was more effective than ethoprop in suppressing nematode populations in corn. Similar results with ethoprop used to control nematodes and increase yields in other intensive cropping systems have been reported (Johnson et al. 1983).

Turnip, grown from seed to maturity in about 60 days when soil temperatures $4 \mathrm{~cm}$ deep ranged from $11^{\circ} \mathrm{C}$ to $24^{\circ} \mathrm{C}$ in March and $16^{\circ} \mathrm{C}$ to $30^{\circ} \mathrm{C}$ in April, supported low numbers of nematodes. Similar results were reported on turnip in other intensive cropping systems (Johnson et al. 1983). Yield of turnip increased four of the six years in MBR-CP treated plots, but not in fenamiphos treated plots, although similar nematode control resulted. The differences in yield of turnip were caused by soil-borne fungal pathogens controlled by MBR-CP (Sumner et al. 1985).

Corn supported moderate to large numbers of all nematodes. While numbers of nematodes were high in corn in June, July, and August, they were lower on 'Funks G-4507' than 'Pioneer 3369A'. Our data indicate that in a turnip-corn-pea production system in fields infested with Meloidogyne incognita and $M$. hapla, 'Funks G-4507' would support fewer $M$. incognita than 'Pioneer 3369A', but neither cultivar would support $M$. hapla. Resistance to $M$. incognita, $M$. arenaria, $M$. javanica (Treub) Chitwood, and $M$. hapla has been identified in hybrids and inbred lines of corn (Baldwin 
and Barker 1970; Ibrahim and Rezk 1978; Norse 1972; Windham and Williams 1987, 1988).

Density of Meloidogyne incognita $\mathrm{J}_{2}$ in plots of 'Pinkeye purplehull' pea following 'Pioneer 3369A' corn was similar to those reported when 'Pinkeye purplehull' pea followed cucumber (Cucumis sativus L.) in an intensive cropping system (Johnson et al. 1983). The resistance of 'Worthmore' pea to $M$. incognita resulted in adequate yields and nematode control without the use of nematicides.

A single application of ethoprop before planting each crop in a turnip-corn-pea cropping system was not beneficial for controlling nematodes. A single application of fenamiphos before planting 'Funks G-4507' corn prevented a rapid increase in nematode population densities near harvest in July and August. However, based on the value of increased yields of all crops compared with the costs of nematicides and application would not justify the use of MBR-CP, DDMENCS, ethoprop, or fenamiphos for nematode control in a turnip-corn-pea cropping system under irrigation.

This study is the result of cooperative investigations by the Agricultural Research Service of the U.S. Department of Agriculture, and the University of Georgia College of Agriculture Experiment Stations, Coastal Plain Station, Tifton. This research was supported by grant funds from the Richard King Mellon Foundation, USDA-ARS, and Hatch appropriated funds.

Baldwin, J.G., and K.R. Barker. 1970. Host suitability of selected hybrids, varieties and inbreds of corn to populations of Meloidogyne spp. J. Nematol. 2: 345-350.

Epperson, J.E., C.C. Dowler, R.B. Chalfant, A.W. Johnson, N.C. Glaze, and D.R.Sumner. 1982. Economic results of pest control intensity for a multiple cropping system. J. Am. Soc. Hortic. Sci. 107: 624-627.
Ibrahim, I.K.A., and M.A. Rezk. 1978. Reaction of corn to Meloidogyne javanica and $M$. incognita. J. Nematol. 4: 289-290 (Abstract).

Jenkins, W.R. 1964. A rapid centrifugal flotation technique for separating nematodes from soil. Plant Dis. Rep. 48: 692.

Johnson, A.W., and G. Fassuliotis. 1984. Nematode parasites of vegetable crops. Pages 323-372 in W. R. Nickle (ed.), Plant and insect nematodes. Marcel Dekker, Inc., New York.

Johnson, A.W., D.R. Sumner, and C.A. Jaworski. 1979. Effect of film mulch, trickle irrigation, and DD-MENCS on nematodes, fungi, and vegetable yields in multicrop production systems. Phytopathology 69: 1172-1175.

Johnson, A.W., C.C. Dowler, N.C. Glaze, and D.R. Sumner. 1983. Effects of intensive cropping systems and pesticides on nematode populations and crop yields. U.S. Department of Agriculture, Agricultural Research Service. ARR-S-14, 36 pp.

Norse, D. 1972. Nematode populations in a maizegroundnut-tobacco rotation and the resistance of maize varieties to Meloidogyne javanica. Trop. Agric. 49: 355-360.

Perry, V.G. 1953. Return of nematodes following fumigation of Florida soils. Proc. Fla. State Hortic. Soc. 66: 112-114.

Steel, R.G.D., and J.H. Torrie. 1960. Principles and procedures of statistics. McGraw-Hill, New York, $481 \mathrm{pp}$.

Sumner, D.R., A.W. Johnson, N.C. Glaze, and C.C. Dowler. 1978. Root diseases of snapbean and southern pea in intensive cropping systems. Phytopathology 68: 955-961.

Sumner, D.R., C.C. Dowler, A.W. Johnson, R.B. Chalfant, N.C. Glaze, S.C. Phatak, and J.E. Epperson. 1985. Effect of root diseases and nematodes on yield of corn in an irrigated multiplecropping system with pest management. Plant Dis. 69: 382-387.

Waller, R.A., and D.B. Duncan. 1969. A bayes rule for the symmetric multiple comparison problem. J. Am. Stat. Assoc. 64: 1484-1499.

Windham, G.L., and W.P. Williams. 1987. Host suitability of commercial corn hybrids to Meloidogyne arenaria and $M$. incognita. An. Appl. Nematol. 1: 13-16.

Windham, G.L., and W.P. Williams. 1988. Resistance of maize inbreds to Meloidogyne incognita and $M$. arenaria. Plant Dis. 72: 67-69. 